\title{
International Expansion Via Acquisition: The Failed Engagement Of Chromalox And Ero
}

Troy A. Festervand, (Email: fester@mtsu.edu), Middle Tennessee State University James R. Lumpkin, (Email: jrlcba@okstate.edu), Oklahoma State University

\begin{abstract}
Growth is a common organizational objective that can be achieved via development and/or acquisition. In this case, a US company seeks to achieve growth, both domestically and internationally, by acquiring a technologically related foreign firm. The logic surrounding the planned acquisition was to expand and improve an existing product line domestically, while gaining immediate access to European markets. Targeted toward upper-division undergraduate business majors and/or graduate business students, this case provides an example of how growth via acquisition can fail for all the wrong reasons.
\end{abstract}

\section{INTRODUCTION}

$\mathscr{J}$ ohn Cox, Senior Product Manager for Chromalox, reluctantly had agreed to be interviewed about his company's recent failed attempt to acquire an Italian manufacturing firm. The project was something of a "favorite child" with John since it was he who had first identified the acquisition opportunity, initiated acquisition discussions, and generally moved the entire project to the point of "doing the deal." Needless to say, he was disappointed when those plans did not come to fruition.

"It was the perfect fit for us. We were looking to augment our existing product line. The price was right. The technologies were complimentary. We were in agreement in virtually all areas, and all of a sudden, the deal was dead. I don't understand where we went wrong."

\section{EXECUTIVE PROFILE}

John Cox obtained his Electrical Engineering Degree from Duke University in 1974. Following graduation and marriage, John took a job with Westinghouse Electrical Corporation as a Field Sales Engineer (i.e., inside sales) in Greenville, South Carolina. A year later, John was promoted and moved to Mobile, Alabama, where he excelled as a Field Sales Engineer.

A career move to Houston, Texas, followed where John took an entry-level position with Texas Instruments (a.k.a., TI). At that time, Texas Instruments was manufacturing and selling the first 16-bit microprocessor chip. With an interest and experience in sales and marketing and a degree in solid-state physics, John migrated to a marketing position with Texas Instruments, ultimately assuming responsibility for the west coast.

John worked with Texas Instruments in Applications Engineering for several years selling microprocessors and board level implementation of microprocessors. After 3 years, he became National Sales Manager for this product line, working with over 400 TI sales engineers. "The difficult part of being sales manager was learning dotted-line motivational skills, not dictatorial kinds of management skills." 
After 5 years with TI, John left his managerial position to join Emerson Electric. He began this stage of his career with CHROMALOX, a division of Emerson, as General Marketing Manager. In that position, John had sales and marketing responsibility for Chromalox Instruments and Controls. In 1982, John was given the charter to develop a standard product line. From that point on, a major transition occurred.

"Indeed, over the next 5 or 6 years, 95\% of what we sold didn't exist in the old days. We had completely turned over as a company as far as the products we sold. We sold temperature controls to a broad base of industrial and commercial customers, everything from integrated control panels for Navy guided missile frigates to controls for McDonald's food station cabinets and everything in between. We were a $\$ 41 / 2$ million company in 1982 at $8 \%$ operating profit. Just a few years later, we were at 17\% operating profit with virtually a totally new mix of products. Our division was in the top $10 \%$ in terms of profitability with over $\$ 200$ million in sales and plans for worldwide growth."

In 1990, John was asked to become National Sales Manager for Chromalox. Shortly thereafter, advertising responsibility also was added to his duties. Under his leadership, a new advertising program, "The Best Under the Sun Program," was created and became a very successful campaign.

Despite his accomplishments and responsibilities, John became disillusioned with some of Emerson's managerial philosophies. After much soul-searching and many discussions with management, John left Chromalox and went to work for the Robert Shaw Company in Knoxville, Tennessee, as Vice-President of Sales and Marketing. Robert Shaw, a manufacturer of liquid level controls for industrial applications.

The marriage did not last long! Reorganization and personnel changes left John in an unacceptable situation. Because of his accomplishments and contacts, John left Robert Shaw and returned to Emerson and his old position, but with the added responsibility for the heating cable and silicon-laminate products division. After turning that operation around, John resumed his duties full-time with the controls division. At that time, the process control division of Chromalox accounted for $20 \%$ of their business.

\section{CORPORATE PROFILE}

Emerson Electric is about a $\$ 19$ billion, Fortune 100 corporation. It started back in the early 1900 's, when electric motors were first being developed. Emerson Motor was one of Emerson's first divisions, focusing on motors for ceiling fans and other applications.

Over the years, Emerson grew via acquisition. In the last decade, $80 \%$ of Emerson's operating units have all been either \# 1 or \#2 in the marketplace. Emerson's strategy has been to go out and acquire a company that has dominated a particular market and a particular segment. With the acquisition's association with the larger company, it typically becomes even more successful. It was not Emerson's style to buy companies in distress. Indeed, Emerson generally was seen as a "White Knight" in acquisition situations. Rather than acquiring a company and cutting it up and selling off the pieces, Emerson has allowed acquisitions to continue existing as constituted. "Emerson will buy a company, support it with capital and management assistance, and then let it grow."

Emerson isn't to be confused with a holding company. "It extends its prerogative to the divisional levels. It has a dominant corporate structure, but the divisions have their own cooperate structures with a President, VicePresident, and staff."

Emerson is one of the few corporate structures that maintain a Triple A graded rating all the time. "When we spent $\$ 1.3$ billion in cash, we dropped to a Double A for 6 months, then we were back up to a Triple A." Emerson boasts that they have never had a quarter where they did not declare a higher dividend to the customer even if it was one penny over all the 70 some odd years of their existence. Emerson stock can be found in most pension funds along with other giants such as General Electric and IBM. 


\section{THE CHROMALOX DIVISION}

While commonly known as Chromalox, the division officially is known as the Edwin L Wiegand Division of Emerson Electric. Wiegand was a German immigrant in the early 1900's that came to the United States. When Thomas Edison was evaluating the illumination properties of electricity through wires, Wiegand was evaluating the heating properties of electricity through wires. Wiegand's idea was to invent a heater where you would not be exposed directly to the heated wire. He took the heater coil or the wire and dropped it down the inside of a tube filled with a mineral called magnesium oxide (MGO), which is a special mineral that possesses the properties of highly dielectric strength and heat transmission.

Wiegand's product became known as a "Tubular Heating Element," which became the first electric stove element (patented in 1915). The entire resistance heating industry grew out of his invention. Today's hot water heater elements, the broilers in ovens, dishwasher and range top elements, all came out of his invention. Globally, this industry is estimated to be worth 3-4 billion dollars annually.

Chromalox or the Wiegand Company grew over the years and dominated its market. Because of their success, the company attracted Emerson's attention. Emerson acquired the company in the 1960's with it becoming the Edwin L. Wiegand Division of Emerson Electric. Chromalox is an acronym for chromium wire and magnesium oxide, so the name Chromalox became the trade name used for the elements sold. Today, the market knows the company and its products lines as simply as Chromalox.

Domestically, Chromalox consists of two divisions that report financially to Emerson as one. The appliance division makes stove and dishwasher elements, etc. at its plants in Vernon, Alabama (a 200,000 sq. ft. facility) and Nuevo Laredo, Mexico, while the industrial division produces elements for a variety of industrial, commercial, and governmental applications. Gross margins in the appliance division are about 20\% (operating profits are single digits), while the operating profits in the industrial division have been as high as $20-22 \%$ (gross margins are $45 \%$ ).

The industrial division originally had heating plants in Ogden, Utah, and Murfreesboro, Tennessee (both about 200,000 sq. ft.). Most of these industrial jobs have been moved to Mexico. Ultimately, the plan was to move all industrial businesses to Vernon and shift the appliance business to Mexico.

Chromalox acquired the controls division in 1978, but didn't move on that charter until 1982, when John Cox was first hired from Texas Instruments. During this period, the overall division saw its profits decline and its market share drop to \#2 in the industry.

According to John Cox, the reasons for their situation were diverse.

"It has to do with a lack of new product introductions. Our performance through our plants fell on hard times. Our Ogden facility shipped less than 50\% on time. Quality also diminished as profitability pressures increased. We also did things that have hurt us. We laid people off which, in turn, caused us to have to use temporaries, which hurt quality further. We promised Emerson high profits and couldn't deliver. We took another layer out of the business to prop up the profits and when we did, that hurt us worse. Then we responded by jacking up prices more. Our list prices were anywhere from 40-50\% higher than our nearest competitor. We also had a high percentage of our income coming from what I call unearned profitability. When customers are in the market every other year or so to buy heaters, they historically have not cared from whom they buy, they are just out to buy that product and they are going to buy it from the industry leader, no questions asked. That used to be us. Purchasing people then started getting quotes (2-3) and when they saw that we were 50\% higher than another competitor, what do you think they did? We were our own worst enemy. We took a customer that had no intention of going anywhere else and messed up the order to the point where that customer had to go to a competitor. Once they did, they then found that not only was our service poor, but our price was too high too. We forced that customer to go elsewhere. 
So, it was a conglomeration of things that caused us to lose market share every year. A large part of our problem was a management's continued denial of what was happening. I guess it felt more comfortable to deny that was happening rather than try to fix it. I didn't know what the solution was. If I had had a solution I would have brought it forward."

\section{THE PLANNED ACQUISITION}

In the mid 1980's, Chromalox set out to define what was needed developmentally in the way of temperature and power controls to facilitate the sale of the heating product. To that end, Chromalox's charge to itself was to develop the $1 / 4$ din temperature controller, referring to the size of the controller's front face (i.e., $1 / 4$ din is $35 / 8$ " $\times 3$ $5 / 8$ " square), as well as the power controller. To be competitive, Chromalox then had to put it all in a box and sell it as in integrated system.

While Chromalox was developing their integrated system, European competitors were developing smaller packages for the European and Asian markets. These 1/8 din and 1/16 din products were touted as a smaller, more efficient replacement for its larger counterpart. Predictions became realities, as US buyers opted for imported products meeting the smaller size. Chromalox and other domestic manufacturers failed to respond and for 4-5 years imported products flooded US markets.

"I refused to move to this form factor. My customers were telling me that they didn't want these little bitty buttons and didn't want these little readouts. But, as the quantity and the volume grew worldwide, their economies of scale got better and better and their prices started falling to the point that everyone was aware of what was going on."

Ultimately, US producers started developing smaller products. Chromalox responded by pursuing two related, yet independent strategies. First, Chromalox increased developmental efforts for the products currently in process. In making this decision and commitment, Chromalox accepted the fact that it had only enough resources to develop one product. Concurrently, the decision was made to outsource remaining product needs. Chromalox wanted to find a supplier with whom it could create an alliance and relationship that might grow into an acquisition.

One day I came across a new company in northern Italy called Ero. They were owned by a group of Italian investors. The president had been the founder of the company. I was first attracted to the product because it is technically a superior product. So, I seized upon the product, went to see them, and over the course of about a year and a half developed a close relationship with its President, Pietro Zanazzo. At that time, Ero was not selling many products in the US and they were looking for a partner to help with US sales. Most importantly, I would learn that Pietro was looking for a "white knight" to help him get rid of his Italian investors. They were becoming troublesome for him and the company. So, this met my criterion of a capability to get the smaller products that were technically superior from a reliable manufacturing source with low cost manufacturing. Despite their limited US presence, Ero was a global competitor. To meet the production needs of their two plants (one in Milano and the other in Malta), Ero was sourcing components from around the world. They were not just an Italian company. "With just under $\$ 20$ million in sales, state-of-the-art manufacturing facilities, excellent design and engineering, the entire company was impressive."

With the business relationship consummated, the US market readily adopted Ero's products, while Chromalox successfully concentrated on its exiting products. Once fully developed, Chromalox's newly developed product line meshed perfectly with its Italian counterpart. Internal successes lead to other successful product spin-offs, which further elevated the position and performance of Chromalox products.

However, as structured, continuing the Chromalox-Ero partnership was counter to Emerson's culture. Given a history of growth via acquisition, Ero was introduced to the notion that Emerson was a good environment to allow a company to become part of and still be allowed to do its own thing. The arrangement appealed to Ero given that its founder wanted to rid himself of his Italian investors and regain control of his company. 
"Over a period of time, I was able to convince him that Emerson would provide that kind of ambiance for him. Emerson would come and properly value his business, pay the investors off, pay him off, and give him a long-term contract to continue to manage the business and that was exactly what he wanted. Everything was set and at that point, after I had the deal done, and only at that point, did I bring it to management."

\section{THE PROPOSAL}

At that time, the industrial division had a new president, an aggressive, bright, shining star from General Motors that was a real "fire eater." He was full of vigor and he wanted acquisitions. The Ero proposal was one of several on the acquisition table and it had been well received at the annual planning conference and formally presented to the Chairman of the Board. All looked to be on target, then the wheels fall off! The President, the project's chief proponent (other than John Cox), was fired.

The President of the Appliance Division assumed the Presidency of the Industrial Division as well. Unfortunately, the new president was not really engaged by the industrial side of the business, so acquisition responsibility for the Industrial Division was delegated to the VP level where the project languished for a year. In the meantime, other acquisition proposals continued to move forward.

Much to John Cox's dismay, the system did little to encourage and/or foster the progression of the proposed acquisition. As he described the situation:

"I was working for one VP, then another, then another. All the while, I am trying to further these acquisitions. Now, as I am bringing acquisitions forward, it's infuriating the VP's that I'm working for to no end. I did not realize until it was too late how my actions were affecting them and their thought process. I managed to alienate every VP that I worked for over a period of time. Each one of them would sooner or later come to be my foe. I was hurting myself, shooting off my toes and didn't even know it, trying to bring these acquisitions to the forefront, specifically the controls acquisitions. At that time, I had envisioned the acquisition to be a way to double, if not triple, the size of our controls content in the division. I saw it as an ability to become a worldwide player with controls manufactured in Europe. We had European subsidiaries that had no controls and were begging me for controls. Our controls were not suitable for European consumption. The Italian product already was certified for the European market and being sold through our French subsidiary."

Despite the fact that the division's president did not embrace the Ero acquisition and VPs continued to change, John Cox again was allowed to present the proposal at the next planning conference. Again, the acquisition proposal got a good review and the mandate of a year to make the deal. At this point in time, the acquisition passed from one set of hands to another. John Cox was no longer a player.

"It was like overnight they knew everything there was to know about temperature control and I have, to this date, not had any direct conversation with Pietro or the Italians or my management on the issue. It was during that period of time that I began to realize that the payoff for me personally was going to be zero. Their intentions were, if they could make it happen, to manage this division just like the other European divisions. The opportunity for us always was to come together and be managed as one unit, so they could do development work for us, where we could have them develop standard products for us, and we would then be able to focus on OEM products. So we are two years into the discussions with the Italians. The European market is beginning to heat up. Pietro is now beginning to have much success with his business. His Italian investors are even more encouraged to sell because he's hot. His sales are hot. This is the time to offload this company if there ever was one. So, they get very impatient and they start pressuring Pietro. Get the deal with Emerson done or we are going to make our own. As you might expect, Pietro got very exasperated with our engagement. I was not having any formal contacts with him other than the vendor relationship, trying to appease him, and trying to offer encouraging words. All the while, I had changed from being an acquisition advocate to becoming neutral. Given the way the deal would be structured (missing out on the synergistic properties I knew could exist), I couldn't see anyway the deal was going to benefit our organization." 


\section{EPILOGUE}

The acquisition proposal again was presented at the planning conference, this time by the division's President. John Cox was at the meeting, but did not participate in this part of the discussion. Again the project was received favorably. Unfortunately, before the President could get to Italy, the Italian investors sold the business to a Chromalox competitor.

"Bottom line, we were scooped! They just came in and made it happen and it took them less than a month to do it! I have not spoken to Pietro since learning that he sold the business. I think he was very disappointed in Emerson's inability to consummate his desire to be an Emerson division. I really don't know what role he played in selling the company. I plan to visit with him to reinitiate our buy-sell relationship since it's still important to us that we keep a good relationship. The new owner may tell him he can't sell to us anymore. I hope that doesn't turn out to be the case. If it does, we are in a pickle as we have no other source for this product. It's unfortunate for everyone, because everyone is a loser in this particular case. We don't have the worldwide, global presence and a competitor of ours becomes a primary supplier to ourselves here in our domestic market and our European subsidiary. Pietro, doesn't know it, but in the long run, he also was a loser." 


\section{INTERNATIONAL EXPANSION VIA ACQUISITION: THE FAILED ENGAGEMENT OF CHROMALOX AND ERO - INSTRUCTOR'S MANUAL}

\section{CASE SYNOPSIS}

Corporate acquisitions typically require extraordinary amounts of time, effort, and capital. If the acquisition is international, then the process is even more complex and demanding. Complicating the process even further are such issues as corporate politics, corporate egos, and corporate processes. It was these latter issues that doomed the international acquisition of an Italian electronics firm, ERO, by US based Chromalox.

After searching for over two years, John Cox, General Manager for the Tennessee Division of Chromalox, decided that his pursuit of a European company with whom his company could partner, would take another direction. Rather than pursue a strategic partnership in which each company would share markets, technology, and development costs, Cox saw an opportunity for his firm to acquire needed product line extensions, gain entry into the European market(s), acquire additional capital assets at a bargain price, and add new technology to an aging company. Ero offered such an opportunity.

Following months of development work and extensive negotiations, Cox and Ero's founder agreed to a deal. The price was right, the "fit" was perfect, the acquisition met the goals of both parties, and the timing was right. All the bases had been covered. What could go wrong? The answer proved to be EVERYTHING!

When Cox presented the deal to Chromalox executives at the annual planning meeting, none of what he thought was important proved to be so. Instead, John found that corporate politics, egos, and etiquette had more to do with completing a successful international corporate acquisition than anything else.

\section{QUESTIONS/ISSUES FOR CONSIDERATION}

1. What happened to the project to cause its failure?

2. What, if anything, did John Cox do wrong? What should he have done or done differently?

3. Was this opportunity as good as was believed?

4. What are the individual and interpersonal issues that are fundamental to the case?

5. What does Chromalox do now?

\section{CASE NOTES}

1. What happened to the project to cause its failure? Several things happened over the course of the project that contributed to the project's demise, but it should be recognized early on that the merits of the acquisition appear to be stated. The deal was/would have been a good one for both parties. Overall, the acquisition had no "champion." Despite his presence and obvious support, John Cox was not in a position to successfully lead the charge or move forward aggressively to complete the acquisition. Given the turnover that was occurring in the organization, the support of the "key player" never came to pass. While the proposal was supported each time it was placed on the table, there was never anyone (at the appropriate level) to step forward, assume the risk, and get the acquisition completed.

It has been said that houseguests and fish are alike in one way. After three days they both start to stink. This project was rapidly assuming the same property. A project that lies around for as long as this project sends the wrong message. If it was such a good deal, why hasn't it been completed? From management's perspective, failure to move in a timelier manner sent up flags of concern, which were not immediately discernible. The project's temporal ambiguity thus exacerbated an already difficult situation.

Internally, there probably was too much "gamesmanship" going on to complete the buy-out. The pursuit of earnings goals, advancement of personal/individual interests, and concern for position, image, and reputation 
on the part of different individuals did little to advance the project's status. Perhaps the lesson to be learned here is that with any project, not only must an organizational and political consensus be established, but also individual needs must be integrated into the overall project strategy.

2. What, if anything, did John Cox do wrong? What should he have done or done differently? John Cox's primary problem was in role definition. More specifically, his error was in not defining roles appropriately. John Cox's role was in identifying and packaging the project, not in selling the project. John should have involved his VP in the project early on, demonstrated the project's merits, and positioned the acquisition as a great opportunity for the company, as well as the VP. Rather than John pursuing the project with Ero's President, an individual at a similar level should have been brought on board at an early date to advance the project.

3. Was this opportunity as good as was believed. Given the information we have, we have to assume the project had merit. It appears as though the project was "a good fit," given the price, assets, technology, and product lines of both companies. One perhaps should ask if there weren't some other issues operating that would have detracted from the project's desirability. According to John Cox, the deal was great. What would one expect John Cox to say about a deal that was the next thing to one of his own kids? Perhaps the deal wasn't as good as we are led to believe. As we will never know the project's full and real merits and demerits, we can only conclude that it was as billed.

4. What are the individual and personal issues that are fundamental to the case? As indicated earlier, the role and impact of individual agendas operating within an organizational context cannot be fully appreciated until experienced. It sometimes is difficult for a student, operating in something of an academic or utopian context, to grasp the notion that an individual(s) within an organization would compromise the overall success, opportunities, performance, etc. of that organization because of individual or personal reasons. We talk about the overall good of the company, and then we see examples of exactly the opposite. Actions, or lack thereof, sometimes are based upon what is best for an individual or specific operating unit without regard to the collective whole. Such appears to be the case here.

5. What does Chromalox do now? Good question! The product line currently enjoys the benefits of the Italian product, but there is significant concern about the company's ability to continue to obtain the product from the newly acquired source. In all likelihood, Chromalox will strive to maintain this relationship as long as possible, but must move to shore up this product line limitation by internal product development or securing another source. Because of budgetary and temporal limitations, it is doubtful that Chromalox will move forward internally. This means that John Cox probably will attempt to locate an Asian source for the needed product. At this point in time, the relationship still exists, but John is pursuing just such a source. No further acquisition efforts are underway. 